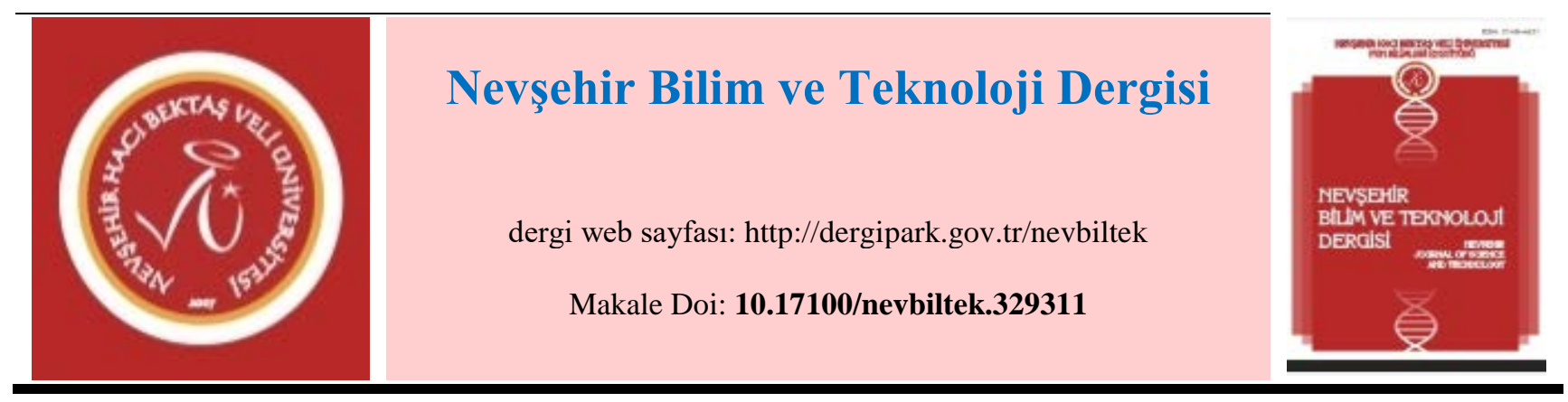

\title{
Kapadokya Bölgesi Nevşehir Yöresi Kültürel Varlıklarının Bozulmalarına Neden Olan Etmenler
}

\author{
Bilal Bilgili ${ }^{1}$ \\ İstanbul Teknik Üniversitesi, Mimarlık Fakültesi, Mimarlık Bölümü, İstanbul
}

$\ddot{\mathbf{O z}}$

Kapadokya Bölgesi doğal, tarihi ve mimari özellikleri bakımından eşsizdir. Doğal bir aşınım sürecinin neticesinde meydana gelmiş olan peri bacalarının bir kısmı insan eliyle biçimlendirilerek, sanatsal özelliği bakımından da özel bir konuma sahip olmuştur. Ancak bu özel yapıların geleceği atmosferik etkiler ve insan aktiviteleri nedeniyle tehdit altındadır. Bu çalışmada, 1985 yılında Dünya Miras Listesi'ne giren Kapadokya Kayalık Alanları ve Kaya Oyma Kiliselerinin bozulmalarına ve bozunmalarına neden olan etmenler araştırılmıştır. Araştırma sürecinde farklı disiplinlerden uzmanların yaptığı deneysel çalışmalar, geçmişte yapılan koruma amaçlı uygulama ve araştırmalar incelenmiştir. Gözlem yapılarak sorunlar koruma bağlamında incelenmiştir. Böylece korumanın ve planlamanın ilk aşaması olan tespit, belgeleme, analiz ve teşhis gerçekleştirilerek, koruma yöntemlerinin belirlenmesine ve öneri getirme sürecine katkıda bulunulması hedeflenmiştir.

Anahtar Kelimeler: Bozunma, Kapadokya, Kilise, Koruma, Mimarlık, Restorasyon.

\section{Causes Leading to the Deterioration of Cultural Heritages in the Cappadocia Region, Nevşehir Province}

\begin{abstract}
Cappadocia Region is unique in terms of natural, historical and architectural features. Fairy chimneys, which are formed by the atmospheric effects and carved by people, are also particular as artistic aspects. However, the future of these special structures are under threat because of the natural causes and human activities. In this study, factors that may cause deterioration of Rock Sites of Cappadocia and its rock-hewn churches, which was listed as a world heritage site in 1985, are investigated. In research process, experimental studies and conservational applications carried out by experts from different disciplines are examined. Conservation problems of the site are investigated as well. Thus, the first stage of protection and planning such as detection, documentation, analysis and diagnosis is performed. Moreover, it's aimed to contribute to the determination of conservation methods.
\end{abstract}

Keywords: Deterioration, Cappadocia, Church, Conservation, Architecture, Restoration.

${ }^{1}$ e-mail: bilgilib@hotmail.com 



\section{Giriș}

“Kapadokya Bölgesi’nin tarihsel süreçteki sınırları değişken olmakla birlikte, jeolojik yapısı ve gösterdiği yöresel mimari özellikler doğrultusunda sınırları kuzeyde Kızılırmak, batıda Aksaray ve Tuz Gölü çöküntüsü, güneyde Niğde İli ve Hasan Dağı, doğuda Erciyes Dağı'ndan itibaren İncesu Yeşilhisar yerleşimlerini kapsayan alan olarak tanımlanabilir [1 ve 2]." 1985 yılında Dünya Miras Listesi’ne giren "Göreme Milli Parkı ve Kapadokya”; Göreme Milli Parkı, Derinkuyu ve Kaymaklı Yeraltı Şehirleri, Karain, Karlık, Yeşilöz ve Soğanlı alanlarını kapsar. Kapadokya Bölgesi'nde tarihsel gelişime bağlı olarak mimari çeşitlenmiş ve farklı yapı tipleri gelişmiştir. Yerleşim alanları, bölgenin jeolojik yapısına bağlı olarak biçimlenen topografyada düz araziye, vadi yamacına ve büyük volkanik tüf kayaların eteğine kurulmuş ve gelişmiştir [1 ve 3]. Özellikle Nevşehir yöresinde kaya oyma yapılar bölgenin karakteristik özelliğini oluşturmaktadır. Peri bacaları içindeki yaşam alanları ve diğer kaya oyma yerleşimler doğal peyzajla uyum içerisindedir. Uçhisar, Ortahisar, Göreme, Ürgüp, Cemil köyü yerleşimleri buna örnek olarak verilebilir. Ayrıca kaya oyma mekânlarla ilişkili ya da ilişkisiz olan yığma yapılarda da benzer uyum görülmektedir. Tüflerin kolay işlenebilir olması peri bacalarının içinde, vadi yamaçlarında ve yer altında farklı kotlarda yatay ve düşey doğrultularda kaya mekânların gelişmesine imkân tanımıştır. Kaya oyma mekânların haricinde, ocaktan çıkarıldığında yumuşak ve kolay işlenebilen, atmosfer koşullarında sertleşen bir malzeme olan tüfler, yığma yapıların inşasında da en temel yapı malzemesi olmuştur. Buna bağlı olarak bölgede farklı işlevlere sahip birçok yapıda bölgenin mimari karakterini yansıtan üç tip yapım sistemi gözlenmiştir. Bunlar kaya oyma (Şekil 1a), yığma (Şekil 1b), kaya oyma ve yığmanın beraber olduğu karma yapılardır (Şekil 1c).
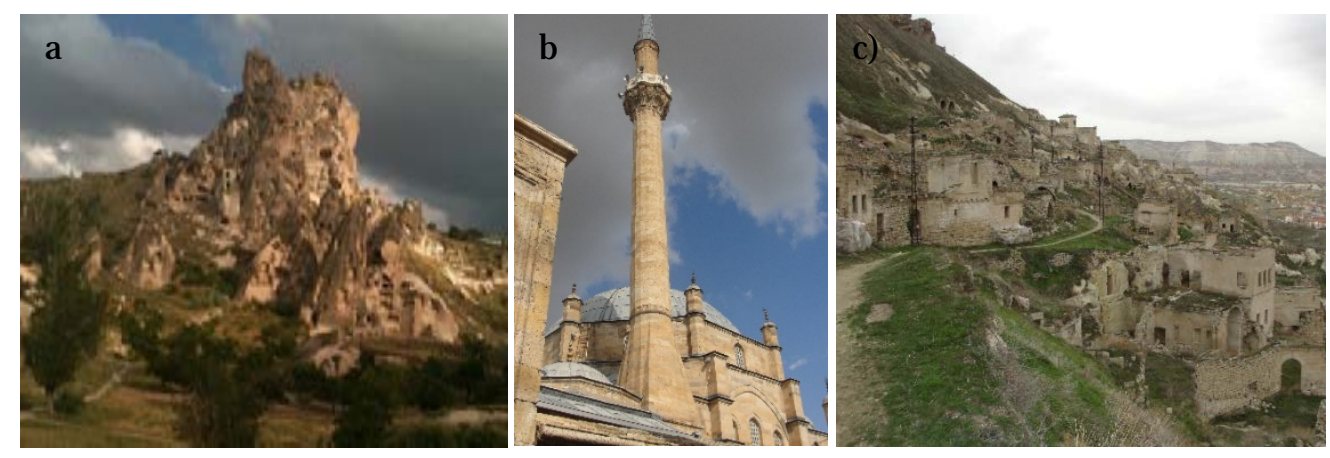

Şekil 1. a) Uçhisar Kalesi (Bilgili Kişišel Arşivi). b) Nevşehir Damat İbrahim Paşa Külliyesi Camii (Bilgili Kişisel Arşivi) c) Ürgüp Kayakapı Mahallesi (Bilgili Kişisel Arşivi)

Kaya oyma mekânlar ya vadi yamaçlarında ya da peri bacalarının içine oyulmuştur. Peri bacalarının içerisine oyulan mekânlar genellikle birkaç katlıdır. Bunlara örnek olarak Ürgüp, Göreme, Ortahisar, Uçhisar, Avcılar ve Zelve de geçmişte kullanılmış ve bugün terk edilmiş durumda olan ya da henüz kullanımda olan kaya oyma mekânlar verilebilir. Kapadokya Bölgesi’nde oyma mimarinin en dikkat çekici örnekleri dinsel mimarlık örnekleridir. Araştırmalar, dinsel mimarlık örneklerinin Hıristiyanlığın erken yıllarından Ortaçağ’ın sonlarına kadar geniş bir zaman dilimine yayıldığını ortaya koymuştur. Kaya oyma mekânlar; bir kaya kütlesine birbiriyle bağlantılı olarak meydana getirilmiştir ve iskân, savunma, ibadet, eğitim, üretim gibi çeşitli işlevlerde kullanılmalarının yanında bölge tarımında önemli bir yeri olan güvercin gübresi elde etmek amacıyla güvercinlik olarak da kullanılmışlardır. Yığma yapım sistemi ile yapılmış yapı tiplerine hemen hemen her yerde ve han, hamam, cami, gibi anıtsal yapılardan sivil mimarlık örneklerine kadar birçok farklı işlevde rastlanmaktadır. Karma yapılar; kayaya oyulan bir mekânın önüne, yığma ek mekânlar eklenerek meydana getirilmişlerdir. Çoğunlukla bir yamaca yaslı olarak meydana gelmekte ve farklı kotlara oturmaktadırlar. İstisna olarak Derinkuyu'da ve Cemil köyünde düz arazinin altına oyulmuş kaya mekânların üstüne, yığma yapıların inşa edildiği arazi çalışmaları sırasında gözlenmiştir. Yer altındaki mekânlar genellikle depo ya da ahır 
olarak, üst mekânlar yaşama mekânları olarak kullanılmıştır. Çalışma alanında Nevşehir Kültür Varlıklarını Koruma Bölge Kurulu 2011 yılı verilerine göre tespit ve tescili yapılmış 2000 civarı kültür ve tabiat varlığı bulunmakta; ancak tescili yapılmamış çok sayıda varlığın olduğu da bilinmektedir.

Çalışma kapsamında doğal peyzajıyla eşsiz güzelliğe ve estetik değere sahip olan, tarih boyunca uygarlıklara ev sahipliği yapan ve bunun izlerini taşıyan Kapadokya Bölgesi’nin doğal, tarihi ve kültürel değerlerinin bozulmasına neden olan, özgünlük ve bütünlüğüne zarar veren faktörlerin neler olduğu araştırılmıştır. Kaya yapıların yapısal bütünlüğünü olumsuz etkileyen iç etkenler ve insan kaynaklı hasarlar bozulma; fiziksel, kimyasal ve biyolojik olarak değişime neden olan doğal etkenler ise bozunma olarak tanımlanmıştır. Çeşitli araştırmalara ve kişisel gözlemlere dayanarak hazırlanan çalışma mimari koruma eylem alanı içerisinde ele alınmıştır. Göreme Milli Parkı içerisinde yer alan Ürgüp, Göreme, Uçhisar, Ortahisar, Zelve ve Çavuşin ile park sınırı dışında kalan Avanos, Acıgöl, Gülşehir ilçelerini de içine alan coğrafyada inceleme yapılmış, alana dair koruma sorunlarının analizi gerçekleştirilmiştir.

\section{Materyal ve Metot}

Geniş bir coğrafi alanı içine alan Kapadokya Bölgesi'nin Nevşehir ili sınırları içerisinde kalan kültür varlıkları ile ilgili 1960'lı yıllardan itibaren farklı disiplinlerden uzmanlar araştırma ve koruma alanında uygulamalar gerçekleştirmektedir. Doğal aşınım sonucu oluşan kayalık alanlar korunması ve müdahale edilmemesi gereken doğal peyzaj olmasına karşılık, insan eliyle biçimlendirilen kaya oyma mekânlar ve özellikle duvar resimleri oldukça kırılgan ve korunması gereken kültür varlığı niteliği taşımaktadır. Bu çalışma, Nevşehir yöresinde kültür varlıklarının bozulmasına neden olan doğa ve insana bağlı etmenleri sorgulayarak doğanın ve insanın ortak eserini bir arada tutmayı ve korumayı hedeflemektedir. Buna istinaden araştırma sürecinde Göreme Milli Parkı içerisinde yer alan Ürgüp, Göreme, Uçhisar, Ortahisar, Zelve ve Çavuşin ile park sınırı dışında kalan Avanos, Acıgöl, Gülşehir ilçelerini içine alan geniş bir coğrafyada inceleme yapılarak alana dair koruma sorunlarının analizi yapılmıştır. Farklı disiplinlerden uzmanların yaptığı deneysel çalışmalar, geçmişte yapılan koruma amaçlı uygulama ve araştırmalar da incelenmiştir. Ayrıca Nevşehir Kültür Varlıklarını Koruma Bölge Kurulu ve Nevşehir Müzesi arşivlerinde de araştırma yapıllmıştır. Araştırmanın veri toplama safhasında sadece yazılı ve görsel kaynaklarla sınırlı kalınmamış, bölgede uzun yıllar çalışmış ve çeşitli projelerde görev almış uzmanlarla da kişisel görüşmeler yapılmış, tecrübelerinden ve geçmişte yapılan çalışmalara dair bilgilerinden istifade edilmiştir.

\section{Bulgular}

\subsection{Bozulmaya Neden Olan İç Nedenler}

İç nedenli hasarlar kaya oyma/yığma yapının konumuna, yapısal ve jeolojik özelliklerine bağlı olarak gerçekleşmektedir. Kayacın bünyesindeki süreksizlikler, malzemeye bağlı özellikler, mekânın oyulduğu kayanın/inşa edilen yapının konumu bozunma sürecini hızlandıran başlıca iç nedenlerdendir.

\subsubsection{Yapısal ve Jeolojik Özelliklere Bağlı Bozulmalar}

Kapadokya Bölgesi’nde doğal kayaların içine oyulan kaya mekânlarda meydana gelen bozulmalar doğrudan kaya şev duraysızlıklarıyla ilişkilidir. Kayacın yapısal ve jeolojik özellikleri kaya yapıların duraylılığını etkiler. Kayacın yapısal jeolojik özelliği; kayanın tipi, süreksizlik tipi, süreksizliklerin yönelimi, süreksizlik açıklıkları, süreksizliklerin devamlı olup olmaması, süreksizlik yüzeyinin pürüzlülüğü ve pürüzlülüğün derecesi, yarık ve dolgu genişlikleri gibi özellikleri kapsar. Tabakalanma düzlemleri, eklem ve faylar gibi süreksizlik tipleri ve bunlarla ilgili yukarıda sayılan diğer faktörler duraysızlıkların meydana gelmesinde etkindir [4]. Genellikle yatay tabakalı olan ignimbiritlerde gözlenen çatlakların çoğu bunların soğuması sırasında meydana gelmiştir. Önemli kırık ve çatlakların boyları yüzlerce metreye ulaşmakta, süreksizlik açıklıkları mikro ölçekten birkaç desimetreye kadar ulaşmaktadır. İgnimbiritlerdeki bu 
çatlaklı yapı, kaya kopmalarına ve düşmelerine neden olmaktadır [5]. Kaya mekânların oyulduğu kayacın yapısal ve jeolojik özellikleri, duraysızlık eğilimi gösteren kaya yapıların zayıflamasına ve çökmesine neden olduğu gibi kaya kütlelerinin insan ya da doğa kaynaklı etkenlerle bozulması da duraylılığı etkiler.

Bölgede jeolojik yapıya bağlı bozulmalar fay ve kırıkların yanı sıra malzemenin içyapısından da kaynaklanmaktadır. Bölgede bulunan tüflerin taşınarak tekrar çökelmesi sonucunda oluşan tüfitler fazla sıkılaşmamıştır ve ufalanabilmektedir. Ayrıca tüfler bol miktarda kil minerali bulundurmaları nedeniyle yağışın olduğu mevsimlerde bünyesine suyu alarak şişmekte ve ağırlaşmaktadır. Aydan ve Ulusay (2007) tüflerin yüksek poroziteye ve düşük birim hacim ağırlıklarına sahip olup, kaya kütlesi olarak iyi kaya kütlesi olarak sınıflandırılmalarına karşın, dayanımları açısından; “zayıf-çok zayıf "ve "atmosferik koşullara karşı oldukça duyarlı” olduklarını ifade etmektedir [6]. Yüksek porozite, bol miktarda kil, zayıf dayanım; ağırlaşan kaya bloklarının süreksizlik durumlarına ve bozunmalarına bağlı olarak özellikle bahar aylarında düşmesine neden olmaktadır. Kaya düşmeleri, Kapadokya Bölgesi’nde zarara yol açan en tipik duraysızlık türüdür. Yamaç topuğunda meydana gelen erozyona bağlı olarak münferit blokların desteklerini yitirmesi, donma-çözülme ile ısınma-soğuma çevrimleri, süreksizliklerde meydana gelen su veya buz basınçları, kayaçlardaki farklı aşınmalar veya insanlar tarafından yapılan kazılar, süreksiz blokların oluşumu vb. nedenler kaya düşmelerine yol açan başlıca faktörlerdir. (Şekil 2a, Şekil 2b, Şekil 3a, Şekil 3b). Özellikle vadi kenarlarında, yamaçlarda, sivri doruklarda ya da kaya mekânların tavanlarından büyük veya küçük parçalar kopmakta ve düşmektedir. Kaya düşmeleri çoğunlukla topuk oyulmalarının, çatlak ve kırıkların yani süreksizliklerin olduğu alanlarda meydana gelmektedir.

Göreme (Şekil 2a, Şekil 3a) ve Zelve Açık Hava Müzeleri (Şekil 3c, Şekil 3d), Uçhisar ve Ortahisar Kaleleri ve Ürgüp (Şekil 2b) ilçesi kaya düşmelerinin yoğun olduğu yerlerdir. Örneğin Ortahisar alanında düşme riski bulunan kaya kütlelerinin olması nedeniyle yakın çevresi boşaltılmış ve ziyarete kapatılmıştır. Kalenin güneyindeki alanın jeolojik nedenlerle boşaltılması alanın harabeleşmesine sebep olmuştur. Dokuz yıl ziyarete kapalı olan Ortahisar kalesi güçlendirme çalışmalarının ardından 2013 yılında kısmen ziyarete açılmıştır. Çarıklı Kilise, tehlikeli görünen ve düşmek üzere olan kaya bloklarının temizlenmesi işi öncesinde 2012 Haziran ayında ziyarete kapatılmıştır. Örneklerde görüldüğü gibi hem çevrelerindeki tarihi yapılar hem de turizm potansiyeli bakımından, önemli olan alanlarda tehlikeli bölgenin boşaltılması ve alanın turizme kapatılması gibi can ve mal kaybını önleyici tedbirler alınsa da alanın özgünlük ve bütünlük değerleri ve turizm potansiyeli bakımından korunması gerekmektedir [7].
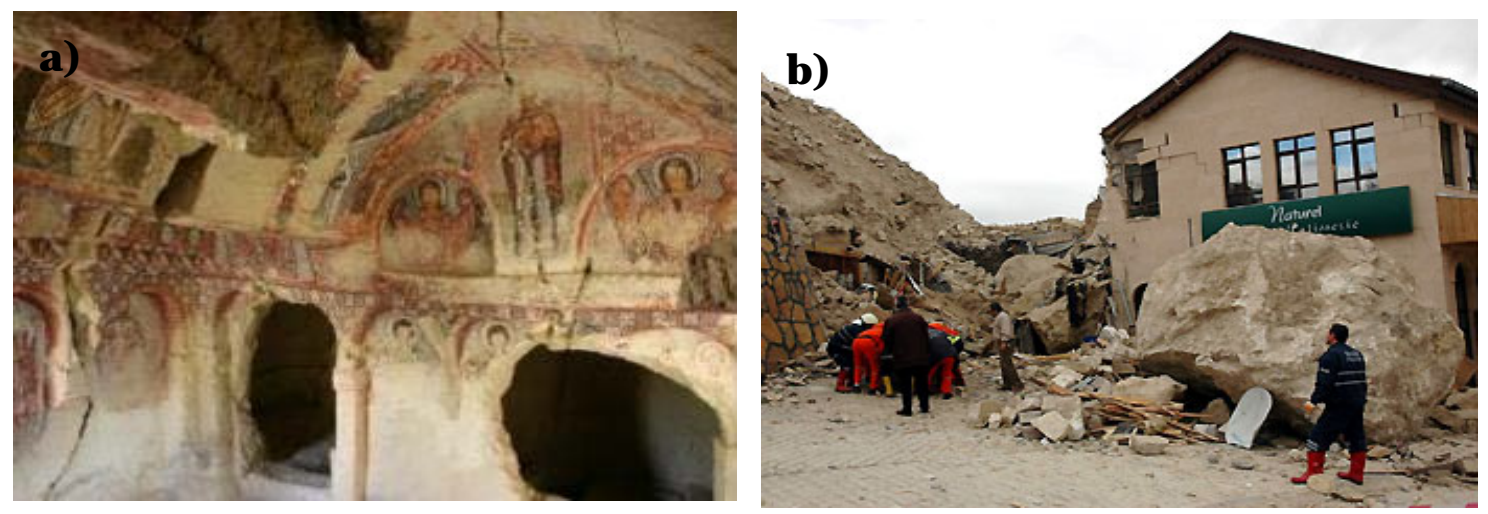

Şekil 2. a) Göreme AHM. Meryem Ana Kilisesi’ndeki yapısal çatlaklar (Bilgili Kişisel Arşivi). b) Ürgüp Temenni Tepesi, 2007 yılı kaya düşme vakası (URL: www.mynet.com/haber/yasam/urgupte-diskoya-kaya-dustu-3-olu-275903-1 ET: 11.03.2013 ) 

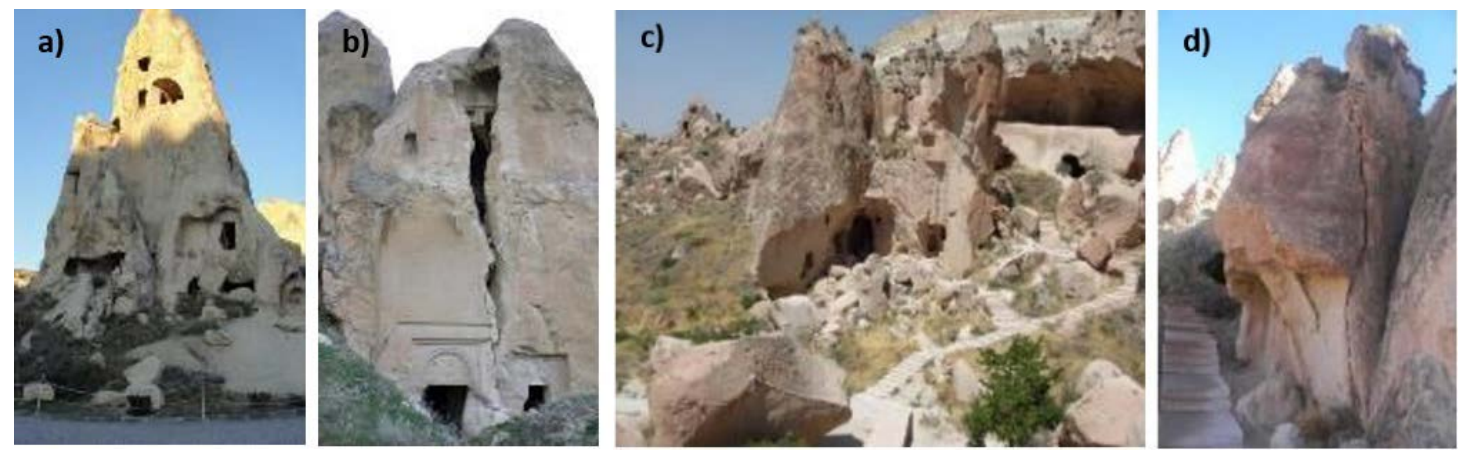

Şekil 3. a) Göreme AHM (Bilgili Kişisel Arşivi). b) Kepez Vadisi (Bilgili Kişisel Arşivi).

c) Zelve AHM (Bilgili Kişisel Arşivi). d) Zelve AHM (Bilgili Kişisel Arşivi).

\subsubsection{Konumdan Kaynaklanan Bozulmalar}

Kaya mekânlar çoğunlukla ya tekil bir kaya kütlesinin içine ya da bir yamaca oyularak meydana getirilmiştir. Yamacın oyulmasıyla oluşan kaya mekânlar; zamanla zemin yapısında meydana gelen değişiklikler, aşınmalar ve hareketlere bağlı olarak zarar görebilmektedir. Örneğin, yamaca oyulmuş olan Elmalı Kilise'nin oyulduğu kayada (Şekil 4a) ve hemen yanındaki büyük kaya kütlesinde vadiye doğru ötelenme gözlenmiş ve korumaya yönelik çalışmalar yapılmıştır. Bir yamacın eteğinde, çukurda veya dere yatağında yer alan kaya yapılar suyun etkisine maruz kalarak bozunabilmektedir. El Nazar Kilisesi (Şekil 4b) örneğinde olduğu gibi yüzey boyunca akan sular zayıf olan tüf katmanını aşındırmaktadır. Aşınan kısmın üzerindeki bloğun askıda kalmasına ve bir süre sonra oluşan gerilim yarıklarına bağlı olarak düşmesine neden olmaktadır. Bazen de dere yatağında yer alan bütün bir kaya yapı yine suyun aşındırmasına bağlı olarak yıkılabilmekte veya kısmen devrilebilmektedir [7].

Kaya yapıların vadiye bakan topuklarında rüzgâr, yağmur ve donma-çözülme sonucu oluşan aşınmanın etkisi çok büyük olmaktadır. Aydan ve diğ. (2007) içinde mekansal açıklık bulunan peri bacaları için yaptıkları analiz sonuçlarına göre ortalama 1000 yıl içerisinde duraysızlık sorunları ile karşılaşma olasılığının yüksek olduğunu tespit etmiştir. Duraysızlıkların kazıdan yaklaşık 100 ile 1200 yıl sonra oluşabileceği verisine göre 9. yy ile 11. yy arasında açılmış ve günümüzde yok olmuş kiliseleri kapsadığı kanısına varmışlardır [8].
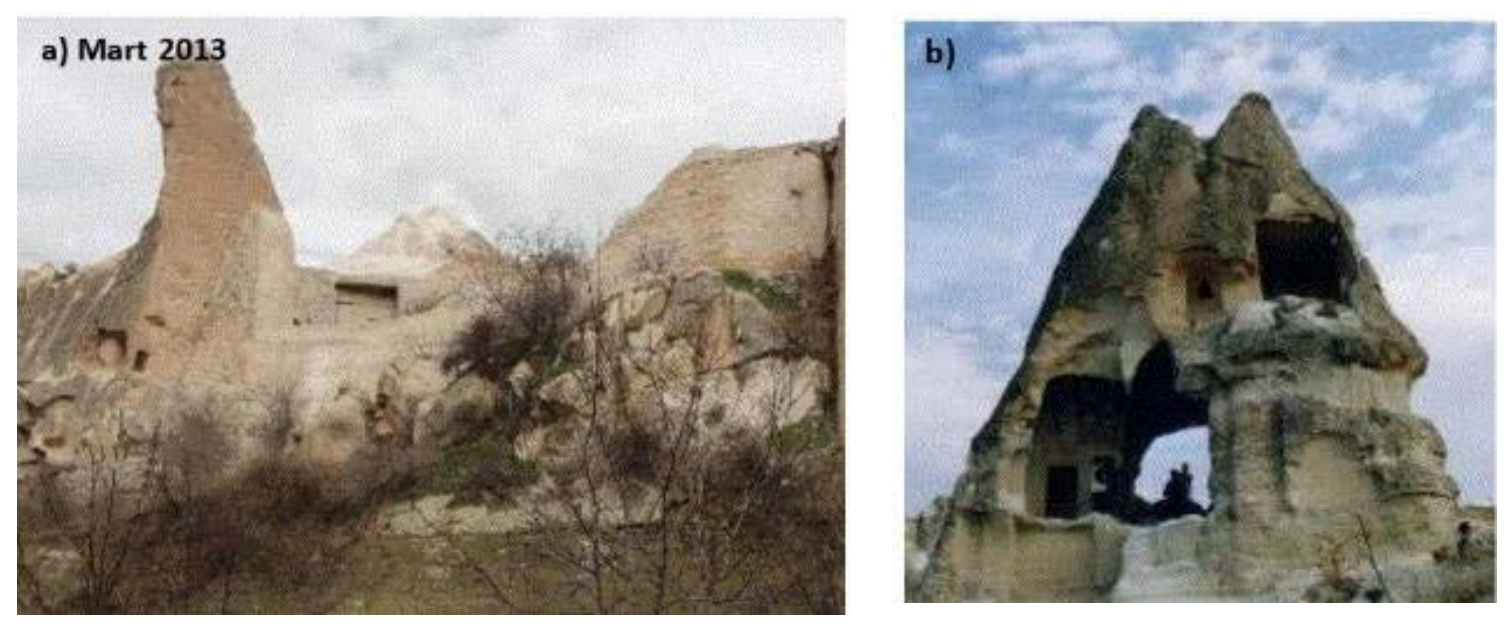

Şekil 4. a) Elmalı Kilise (B.Bilgili Kişisel Arşiv). b) El Nazar Kilisesi onarım öncesi (Rıdvan İ̧̧ler Kişisel Arşiv).

\subsection{Bozunmaya Neden Olan Dış Nedenler}

Kapadokya kayalık alanları jeolojik süreçler ve doğal etkenlerle bugünkü şeklini almıştır. İnsan eliyle ya da doğanın tetiklemesiyle kayalık alanlarda veya kaya yapılarda denge koşulu değişmekte ve duraysızlıklar meydana gelmektedir. Doğal etkenler sonucu meydana gelen bozunma fiziksel, kimyasal ve biyolojik olmak üzere üç başlık 
altında toplanabilir. İnsan aktivitesinden kaynaklanan faktörler ise terk, turizm, vandalizm, hava kirliliği, trafik, imar etkileri, kötü kullanım ve onarımlardır.

\subsubsection{Doğal Etkenler}

a) Fiziksel Bozunmalar:

Kayaçlarda bozunma fiziksel, kimyasal ve biyolojik olmak üzere üç şekilde oluşmaktadır. Malzemenin direnci bu nedenlerle meydana gelen bozunmalara bağlı olarak azalır. Tüf malzemeler, nem, yağmur, toprak birikimi, don, sıcaklık değişimleri gibi doğal nedenlere bağlı olarak özelliklerini zayıflatan değişimlere uğramaktadır.

Suya bağlı erozyon Kapadokya Bölgesi’nde peribacalarının en çok maruz kaldığı bozunma türüdür. Suyun kayalık alanlardaki hareketi, sızıntı suları ve yüzeyden akıntı biçimde olmak üzere iki türlüdür. Yüzey suları kaya yapıların yüzeyinden akarken zayıf ve yumuşak olan tüfleri aşındırmaktadır. Örneğin volkanik camlar, tüfler içerisinde en stabil olmayan bileşiklerdir ve diğer bileşik minerallerden daha kolay ayrışmaktadır [9]. Zamanla oluşan oyukların üst kısmındaki askıda kalan kaya kütlesinde gerilim yarıkları meydana gelmekte ve kaya kopmalarına neden olmaktadır (Şekil 3d, Şekil 4b). Topuk aşınması olarak da ifade edilen ve çoğu peribacasında görülen bu bozunma türü, kaya yapının zemine yakın kısımlarının su etkisiyle yüzey kaybına uğraması sonucu meydana gelir. Alt kısımları aşınan kaya, üstte konsol olarak çalışmaya başlamakta, bir süre sonra aşınmalara ve bozunmalara maruz kalan bu kısım da koparak düşmektedir. Su yüzeyden akarken yukarıdan aşağıya doğru hızlanmaktadır. Bu nedenle yukardan aşağıya doğru erozyonda da artış gözlenmektedir. Eriyen karlar ve yağmur suları; kaya kütlesini oluşturan tüf malzemenin içerisine suyun süzülmesine ve kayalardaki geçirgen boşluklu yapının dolmasına neden olmaktadır. Donma sonucu gözenek suyu basıncını arttırarak kaya ayrılmalarını tetiklemektedir. Bunun neticesinde can ve mal kayıpları gibi doğrudan, turizm geliri kayıpları gibi dolaylı zararlar oluşmaktadır. Tüf ve ignimbirit gibi kaya birimlerinde yağışlarla cepheden inen ya da kapilarite ile temelden yükselen sular yapı içerisinde ilerlemekte ve iç bölmelerde nem artışına yol açmaktadır. Su içeriğindeki artışa bağlı olarak taşın fiziko-mekanik özelliklerinde değişme olmakta ve bozunma süreci hızlanmaktadır. Yüzeylerde su sızıntılarına bağlı olarak parça kopmaları, tozlanma, kavlamalar, yapraklanmalar meydana gelmektedir (Şekil 5a, Şekil 5b, Şekil 6b, Şekil 7a). Özellikle kaya oyma mekânlarda bozunmanın temel nedenlerinden biri çatlaklardan sızan ve drene edilmeyen yağmur suları ile bazen çevreden sızan pis sulardır. Kaya kütleleri içerisindeki geçirgen yapı süzülme hızını arttırmakta ve sızan sular tüflerin mühendislik parametrelerini zayıflatmaktadır [6]. Mekân üst örtülerinde veya kaya cidarlarında meydana gelen çökmeler ve yıkılmalar da suyun etkisini hızlandırmaktadır. Suyun bir diğer etkisi de tüfün kısmen, volkanik camların ve bazı kaya parçalarının ise yüksek oranda değişerek smektit türü kile dönüşmesidir. Killeri oluşturan tabakaların arasına sıvıların girmesi sonucu tabaka kalınlıkları değişir ve şişer. Bunun sonucunda gerilim çatlaklarının boyutlarında ve renk değişimlerinde artış meydana gelmektedir [9]. 

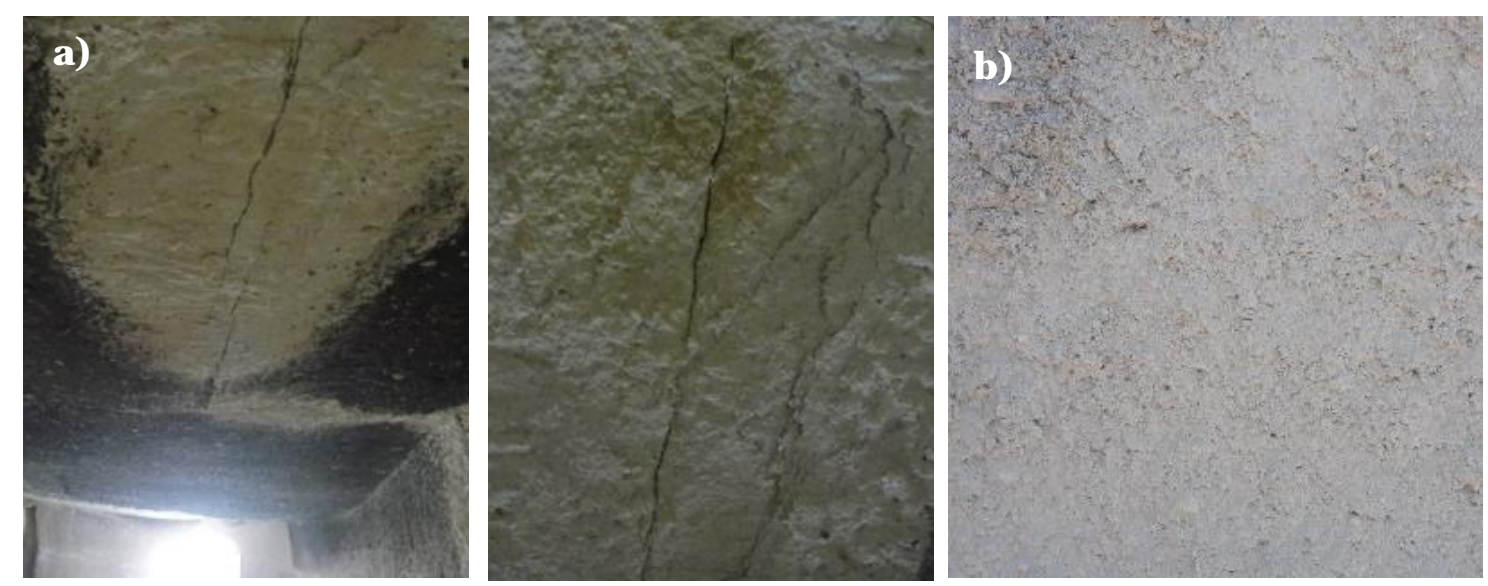

Şekil 5. a) Yılanlı Kilise Yemekhanesinin tavanı (B.Bilgili Kişisel Arşiv). b) Göreme AHM yoğun bir bozunma etkinliği sonucu erozyona uğrayan tüf tabakası (B.Bilgili Kişisel Arşiv).
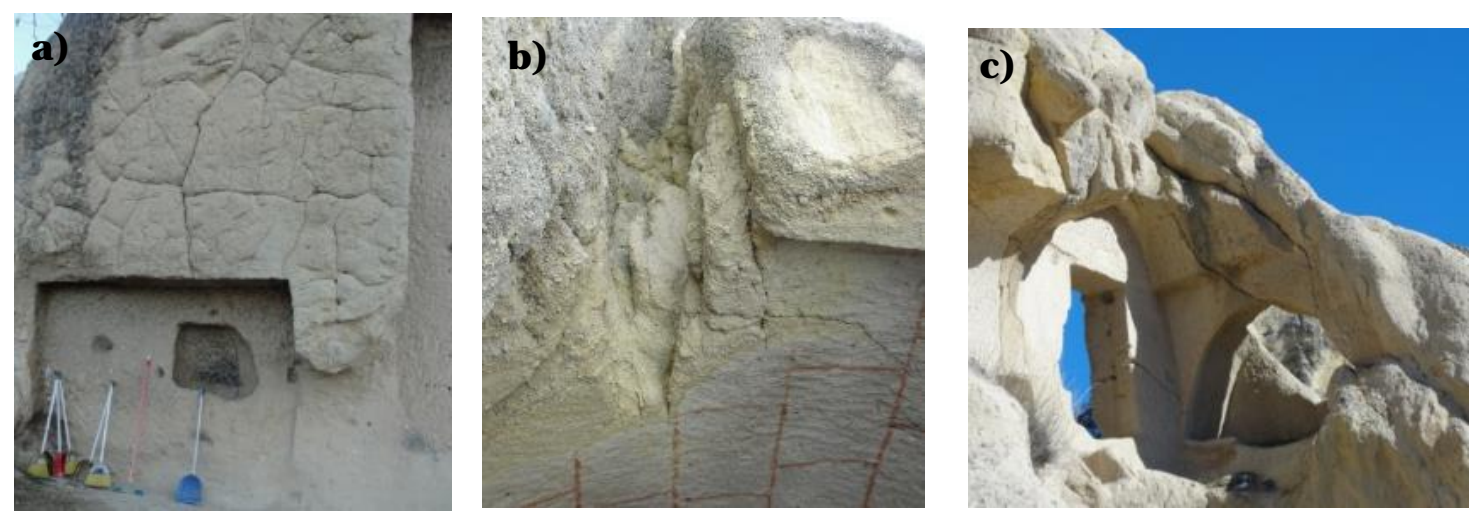

Şekil 6. a) Göreme Aziz Basil Kilisesi batı tarafı (B.Bilgili Kişisel Arşivi). b) Göreme AHM. Pantokrator Kilise yıkılan giriş üst örtüsü ve su akışına bağlı erozyon (B.Bilgili Kişisel Arşivi). c) Göreme AHM (Nevşehir Müze Müdürlüğü Arşivi).

Rüzgâra bağlı erozyon bölgede görülen bir diğer erozyon çeşididir. Bölgede çeşitli bozunma etkinliklerinin sonucunda aşınmış ve ufalanmış toz zerrecikleri yoğun bir şekilde gözlenmektedir. Toz ve toprak taneciklerinin fazlalığı, düşük nem ve zayıf bitki örtüsü rüzgâr erozyonunu arttırmaktadır. Meteoroloji Genel Müdürlügü’nün ölçümlerine göre Nevşehir'de günlük en hızlı rüzgâr 12.03.1968 tarihinde ve 125,3 km/s'dir. Rüzgâr hızının bu kadar yükseldiği alanda, toz parçacıklarının kaya yüzeylerinde bulunan gevşek dokulu ya da zayıf çimentolaşmanın olduğu yüzeylere çarpması sonucu kaya yapıları erozyona uğramaktadır. 1987-92 yılları arasında yapılan ölçümlere göre doğal ve insana bağlı gelişen erozyonun y1llık $0,4 \mathrm{~cm}$ olduğunu tespit etmiştir.

Sıcak-soğuk farklarına ve çevrimlerine bağlı olarak da malzemenin dayanımında değişme meydana gelmektedir. 1970-2011 yılları arasında yapılan ölçümlere göre bölgede ölçülen en düşük sıcaklık 28.01.2000 tarihinde $-21,2{ }^{\circ} \mathrm{C}$, en yüksek sıcaklık 30.07.2000 tarihinde $39,5{ }^{\circ} \mathrm{C}$ dir. 1986 yılında St. Barbara Kilisesi'nde 18-19 Mayıs günlerinde yapılan ölçümlerde, ölçüm yapılan noktaların bazılarında maksimum sıcaklık $41{ }^{\circ} \mathrm{C}$ minimum sıcaklık da 9 ${ }^{\circ} \mathrm{C}$ olarak tespit edilmiştir. Bir noktadaki maksimum sıcaklık değişmesi $28{ }^{\circ} \mathrm{C}$ minimum değişme $2{ }^{\circ} \mathrm{C}$ olmuştur [11]. $\mathrm{Bu}$ verilere göre hem gün içindeki hem de mevsimlik sıcaklık farklarının yüksek olduğu görülmektedir. Yazın sıcak günlerde genleşen malzemeler, soğuk kış günlerinde dona maruz kalmaktadır. Aynı şekilde gündüz ısınıp genleşen malzemeler gece soğuyarak büzülmektedirler. Isı farkları, donma çözülme etkileri sonucunda tüf malzemeler yorulmakta, gevşemekte ve yıpranmaktadır.

Donma-çözülme çevrimleri ile süreksizliklerin ilişkisi bozunma sürecini doğrudan etkileyen faktörlerdendir. Rüzgâr, yağmur, don ya da kayanın oluşum sürecinden kaynaklanan aşınmış bölümlerde, çatlak ve yarıklar meydana gelmektedir. Çatlaklara giren su donduğunda kama etkisi yaparak, çatlakların büyümesine ya da kaya kütlelerinin 
kopmasına neden olmaktadır. Ayrıca çatlak ve yarıklara sızan sular, kış mevsiminde donma-çözülme döngüsüne tabi olması ve sık sık tekrar etmesi sonucunda tüfün yapısal özelliğini bozmaktadır. Bu durum zayıf bitkileşme, dik yamaçlar ve zayıf çimentolaşma gibi durumlarla birleştiğinde toprak erozyonunu da arttırmaktadır. (Şekil 7a, Şekil 7b).
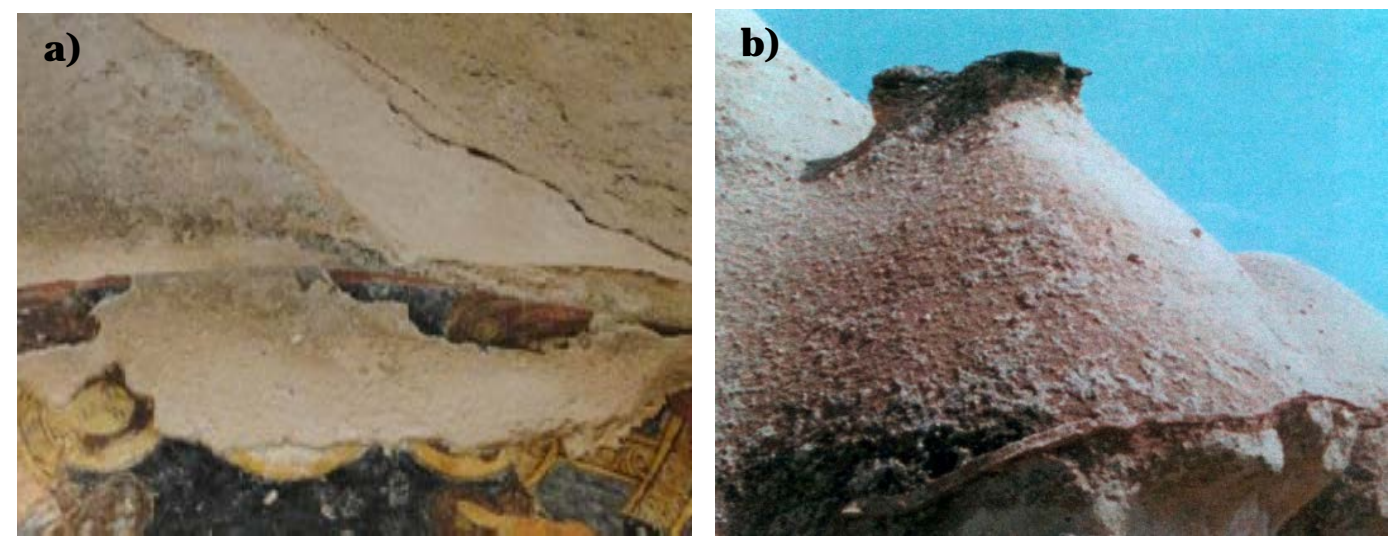

Şekil 7. a) Gülşehir Aziz Jean Kilisesi, fresk kaplı yüzeylerde neme bağlı tozuma ve kavlama (B.Bilgili Kişisel Arşivi). b) Göreme Kılıçlar Kilisesi’nin üst örtüsü, su ve rüzgara bağlı erozyon (Nevşehir Koruma Kurulu Arşivi).

Topal'a göre (1995) bölgede 1990'da 68, 1991'de 38, 1993'te 62 defa donma çözülme çevrimi gerçekleşmiştir [10]. Ayrıca Topal ve Doyuran (1998) kışları soğuk ve yağışlı, yazları sıcak ve kuru olan bölgede, donma-çözülme çevrimi yılda ortalama 50 defa tekrar ettiğini belirtmektedir [9]. Islanma-kuruma, donma-çözülme çevrimlerine maruz kalan yüzeylerde kabarma veya dökülmeler görülmektedir [9]. Islanma-kuruma çevrimleri sonucu tüf malzemede ağırlık kaybı, porozite artışı, renk değişimi, su emme kapasitesinde artış da gözlenmişstir [9]. Donma-çözülme çevrimleri tüf malzemenin fiziksel görünüşünü ve ağırlığını değiştirmekte, ufalanıp dağılmasına neden olmaktadır. Topal ve Doyuran'ın (1998) yaptığı testlerle tüf malzemenin donmaya karşı hassas olduğu ve düşük durabilite gösterdiği ortaya konulmuştur [9].

b) Kimyasal Bozunmalar:

Tüf malzeme içinde kayda değer miktarda tuz olmamasına rağmen buzlanmayı önlemek için tuz kullanımı ya da çimento kullanımı sonucunda oluşan tuzlar gibi çevrede potansiyel tuz kaynakları bulunmaktadır [9]. Topal ve Doyuran tuzların tüf kaya üzerinde bozunmasını incelemek üzere yaptıkları testleri üç defa tekrar edebilmiş, dördüncü döngüde kayaç tamamen dağılmıştır. Caner (1995) ise 2 defa yapabilmiş, üçüncü defa yaptığında tüf malzemenin dağıldığını tespit etmiştir [12]. Buna göre; kayacın dayanımındaki azalma üzerinde en büyük etkiyi tuz kristallerinin bıraktığ 1 tespit edilmiştir [9]. Kayacın kimyasal ve mineralojik özelliklerine bağlı olarak tüf malzemelerin atmosfer ile teması sonucunda kimyasal bozunmalar meydana gelir. Bazı kaya kilise duvar resimlerinde görülen kırmızımsı renk değişimi biçimindeki bozunma da bundan kaynaklanmaktadır. Biyotit ve kaya parçalarında demir oksidasyonuna bağlı renk değişimleri veya volkanik camların kimyasal bozunması sonucunda simektit grubu kil meydana gelmesi buna örnek olarak verilebilir. Smektit grubu killer özellikle eklemler civarında daha yoğun bulunmaktadır [9]. Su alarak şişen killer bozunma sürecini hızlandırmaktadır.

c) Biyolojik Bozunmalar:

Kayaların üzerinde özellikle kuzey yüzeyinde liken ve yosun oluşumları gözlenmiştir (Şekil 8b). Likenler nemli yüzeylerde, güneş ışı̆̆ının ve rüzgâr erozyonunun az olduğu yüzeylerde gelişmiştir. Likenler belli bir büyüklüğe kadar kaya yüzeyini muhafaza etmekte daha fazla büyüdüğü zaman üzerine tutunduğu kaya yüzeyinde mikro bölünmelere neden olmakta, parça kopararak düşmekte ve tüf kayaya zarar vermektedir. Caner vd. (1995) yaptığ1 çalışmaya göre likenlerin oluşturduğu mikro çatlaklar ile bağlayıcı malzeme ve mineral kompozisyonunda da değişism meydana gelmiştir [12]. Liken kaplı yüzeylerde üst $2 \mathrm{~cm}$ 'lik tabakada az miktarda mekanik ve kimyasal bozunma 
gözlenmiştir [9]. Liken kaplı yüzeylerde kimyasal bozunma neticesinde meydana gelen smektit grubu kil miktarının çok daha az olduğu tespit edilmiştir. Ayrıca fiziksel özelliklerinde de kayda değer bir değişiklik gözlenmemiştir [9].

Rüzgârla birlikte taşınan tohumlar kaya yüzeylerine, çatlaklara, yapıların üst örtülerine, duvar oyuklarına ya da boşalmış derzlere yerleşebilmektedir (Şekil 8a). Bölgede her ne kadar zayıf bitkileşme görülse de buralara yerleşen bitkiler kökleri vasıtasıyla parça kopmalarına neden olmaktadır. Ayrıca kış aylarında yağış sonrası çatlaklardan içeri su sızıntısının olduğu bölgelerde yosun oluşumu da gözlenmiştir.

Bölgedeki sosyal yaşantının bir yansıması olarak karşımıza çıkan, güzellik ve özellikleriyle de dikkat çeken güvercinliklerde biriken hayvansal artıklar da bozunmalara neden olmaktadır. Bazı kiliselerin içine tüneyen güvercinlerin kanat çırpmaları, zayıflamış olan duvar resimlerinin dökülmesine neden olabilmektedir. Bunun yanında duvar resimlerinin sıva tabakasının altına yerleşen böcek larvaları kaçış delikleri açmakta ve dışarı çıkarken üstündeki sıva tabakasını atmaktadır. Ayrıca duvar resimlerinin üzerinde böcek dışkısı olarak tanımlanan beyaz renkli birikintiler tespit edilmiştir. Benzer bir durum kiliselerin dışında da gözlenmiştir. Şekil 8c'de görüldüğü gibi onarım sıvasının altına yerleşen larvalar çıkış sırasında üzerindeki sıva tabakasının bozulmasına neden olmaktadır [7, 13, 16].
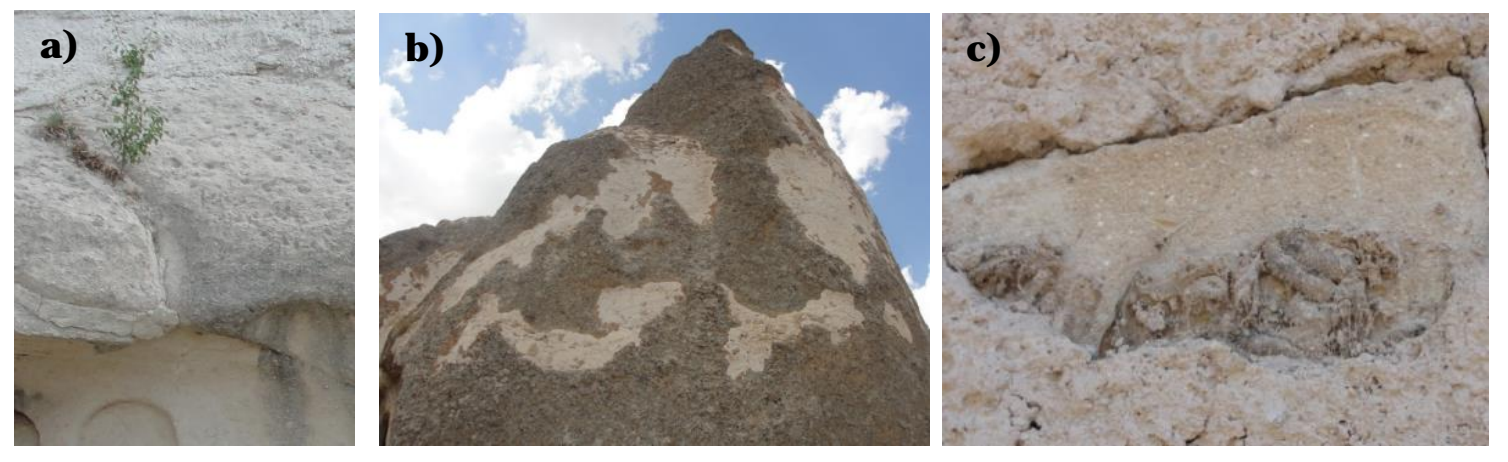

Şekil 8. a) Göreme Yılanlı Kilise yemekhane girişi, çatlağa yerleşen bitki (B.Bilgili Kişisel Arşivi). b) Şahinefendi Kırk Şehitler Kilisesi, liken ve yosun kaplı yüzeyler (B.Bilgili Kişisel Arşivi). c) Gülşehir Aziz Jean Kilisesi sıva tabakası altına bırakılan larvalar (B.Bilgili Kişisel Arşivi).

\subsection{2. İnsanların Neden Olduğu Hasarlar}

Tarihi yerleşim alanlarının sosyal, ekonomik, tarihi gelişim veya değişim süreci, can güvenliğini ve sağlığı tehdit eden durumlar sonucu afet bölgesi ilan edilmesi gibi nedenlerle terk edilmesi, bölgede bulunan doğal ve geleneksel dokunun bozulmasına, anıtsal yapıların bakımsız kalmasına neden olmuştur. 1969 yılında Ürgüp Kayakapı Mahallesi (Şekil 9a) afet bölgesi ilan edilerek burada yaşayan halk Damsa Çayı'nın doğusunda inşa edilen afet konutlarına taşınmıştır. 1984 yılında tamamlanan tahliye sürecinin ardından yaklaşık 20 yıllık bir süre zarfında sahipsiz ve bakımsız kalan geleneksel doku hızla tahrip olmuştur. 1967 yılında milli park planlama çalışmaları ile ilgili girişimler gerçekleştirilirken öte tarafta 1969 sonrasında 7269 sayılı afet yasası kapsamında tahliye kararlarının alınması birbiriyle çelişen bir tutum sergilemiştir.

Kapadokya Bölgesi Hıristiyanlık dini mensuplarının yaşadığı önemli bir merkez olmuş, Türkler'in Anadolu'ya yerleşmesinden sonra zamanla Hıristiyan nüfus azalmıştır. 1923’teki mübadele ile birlikte Sinasos’ta (Şekil 9b) olduğu gibi kalan Hıristiyan halkında büyük çoğunluğu göç etmiştir. Bu terklerin sonucunda dini yapılar başta olmak üzere çok sayıda eser bozulma ve yok olma sürecine girmiştir $[7,16]$. 

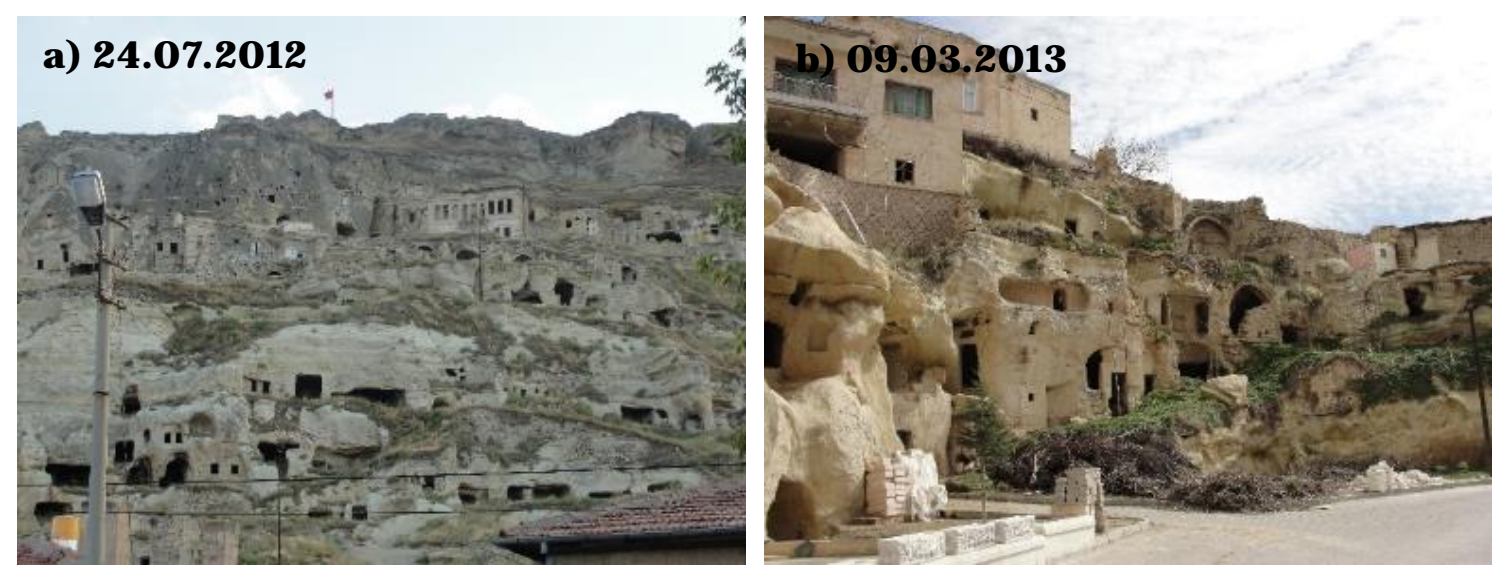

Şekil 9. a) Ürgüp Kayakapı Mahallesi (B.Bilgili Kişisel Arşivi). b) Mustafapaşa-Sinasos (B.Bilgili Kişisel Arşivi).

Kapadokya Bölgesi'nde bulunan çok sayıda kilise terk edilmesinin ve sahipsiz kalmasının akabinde vandalizme maruz kalmıştır. Kiliselerde bulunan duvar resimlerinin ulaşılabilen bölümlerinin özellikle yüz ve gözleri sivri uçlu aletlerle kazınmış, ulaşılamayan bölgelere ise taş atmak suretiyle tahrip edilmiştir (Şekil 10c). 1800’lerin sonlarından itibaren birçok yapıda Türkçe ve Yunanca yazılmış grafitiler mevcuttur. Bazı kiliseler depo, ahır, güvercinlik gibi çeşitli işlevlerle kullanılmış ya da gelişigüzel mekânlar eklenmiştir. Bu da yapıların mekânsal bütünlüğüne ve özgünlüğüne zarar vermiştir. Kilise içlerinde ve kaya mekânlarda ateş yakılması nedeniyle yüzeylerde yoğun is tabakaları meydana gelmiştir. Örneğin Tatlarin Kale Kilise içerisinde pekmez kaynatmak için ateş yakılmış (Şekil 10b) ve depo amacıyla ek mekânlar oyulmuştur (Şekil 10a). Sarıca Kilise’nin bazı mekânlarında yapının, mekânın, yüzeyin özelliğine bakılmaksızın ve bilinçsizce güvercinlikler açılmış, güvercin atıklarının depolanması için de zeminde derin çukurlar kazılmıştır. Bugün bile, önüne geçilmeye çalışılsa da, define arayanların bölgedeki Antik kentlerde kaçak kazı yaptığı bilgisi Nevşehir Müze Müdürü’nden edinilmiştir [7].
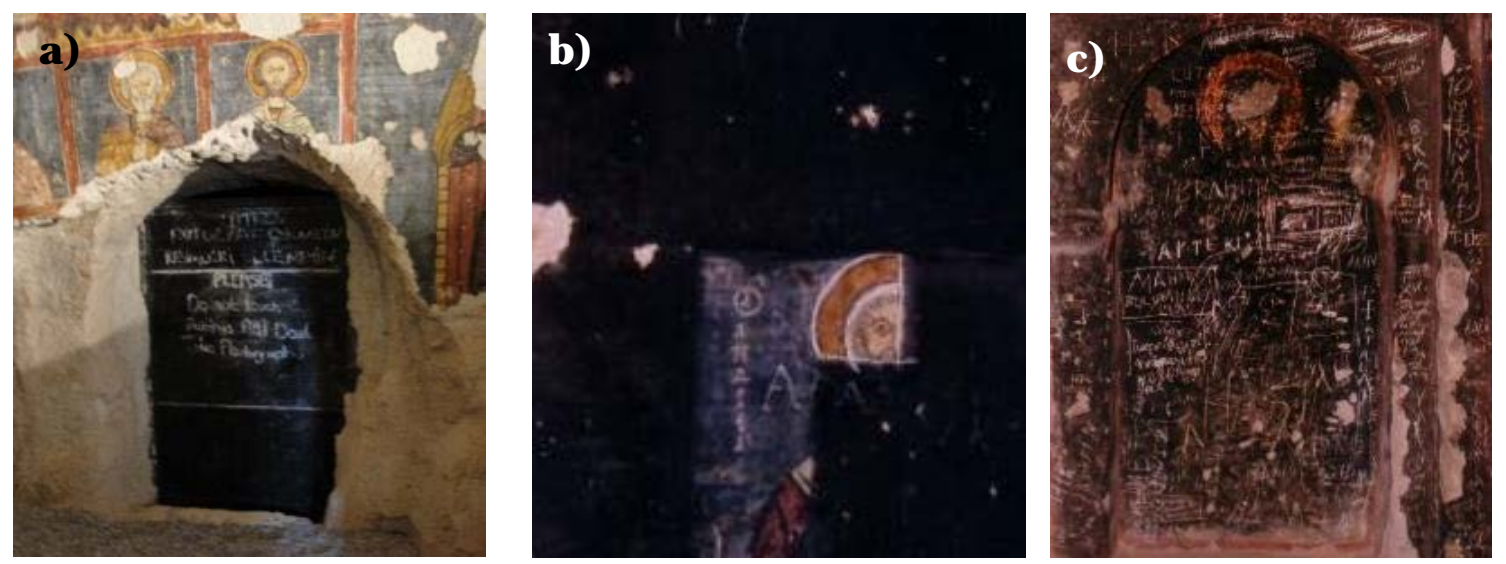

Şekil 10. a) Tatlarin Kale Kilise içerisine sonradan oyulmuş mekân (B.Bilgili Kişisel Arşivi). b) Tatlarin Kale Kilise onarım öncesi, is tabakası (R.İ̧ler Kişisel Arşivi). c) Gülşehir Aziz Jean Kilisesi onarım öncesi, fresk yüzeylerde grafiti (R.İşler Kişisel Arşivi).

Bölge turizm hareketlerine bağlı olarak turistik gezi, konaklama, dinlenme etkinlikleri ve hediyelik eşya satışları gibi ticari faaliyetlerden iyi bir kazanç elde etmektedir. Turizm ayrıca kültür varlıklarının bakımı ve onarımı konusunda da itici bir güç olabilmektedir. Ancak bölgedeki yoğun ziyaretçi akışı bölgedeki kültür ve doğa varlıklarını tehdit eder düzeye ulaşmakta ve aşındırıcı bir etki yapmaktadır. Kapadokya kaya oyma kiliselerinde Göreme Açık Hava Müzesi gibi denetimi oldukça yüksek olan bir alanda bile ziyaretçiler kaya mekânlara kontrolsüz girip çıkmakta, mezar çukurlarının üzerinde gezinmektedirler (Şekil 11b). Birçok kilisede buna bağlı olarak taban aşınması meydana gelmiştir. Buna önlem olarak bazı kiliselerde ahşap yürüme platformları yapılmış, ziyaretçilerin basabilecekleri alan sınırlandırılmıştır. Fakat platformlar üzerinde toplanan tozlar ziyaretçi yoğunluğunun fazla olması sebebiyle 
yükselmekte ve fresk kaplı yüzeylerde, silmelerde tozumaya neden olmaktadır. Ağustos 2012'den sonra tozumanın önüne geçmek amacıyla bazı kiliselerde platformlar üzerine halı serilmiştir. Tabii ki bu tür çözümlerin tozumayı engellemesi beklenemez. Ziyaretçi yoğunluğunu kontrol altında tutmak amacıyla ziyaret süresi birkaç dakika ile sınırlı tutulmaya çalışılmaktadır. Her kilisenin önünde duran görevliler fotoğraf çekilmemesi, zaman sınırına riayet edilmesi, içerde konuşulmaması gibi uyarılarda bulunmaktadır. Buna rağmen kiliselere bir anda çok sayıda insan girmekte, flaşlı fotoğraf çekmekte ve bu durum fresklere zarar vermektedir. Çok sayıda insanın girdiği kiliselerde insanların nefes alış verişlerinden kaynaklanan nem de yine fresklere zarar vermektedir. Bölgedeki önemli bir turistik etkinlik balon turlarıdır. Göreme Açık Hava Müzesi’nin hemen yanında balon turlarının düzenlendiği tesis alanı bulunmaktadır (Şekil 11a). Tesisin işlev ve estetik görüntü bakımından uygun olmayan bir yerde olduğu söylenebilir [7, 16].

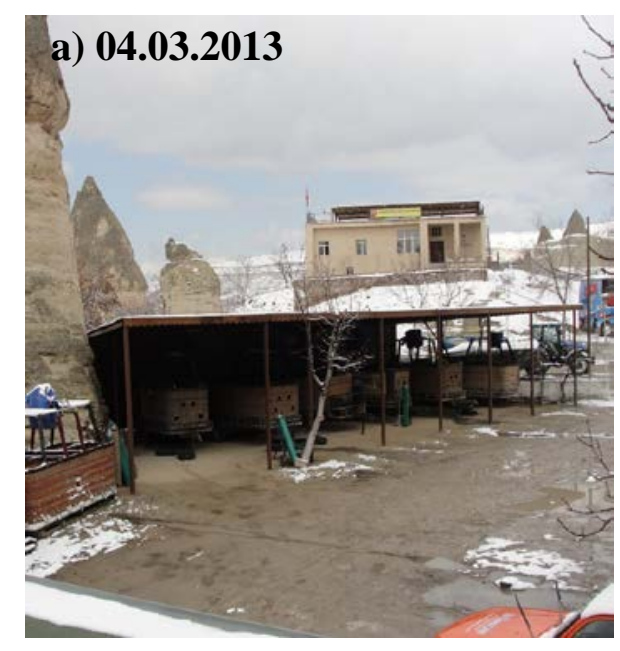

Şekil 11. a) Göreme AHM balon kalkış yeri ve arkada hizmet birimi

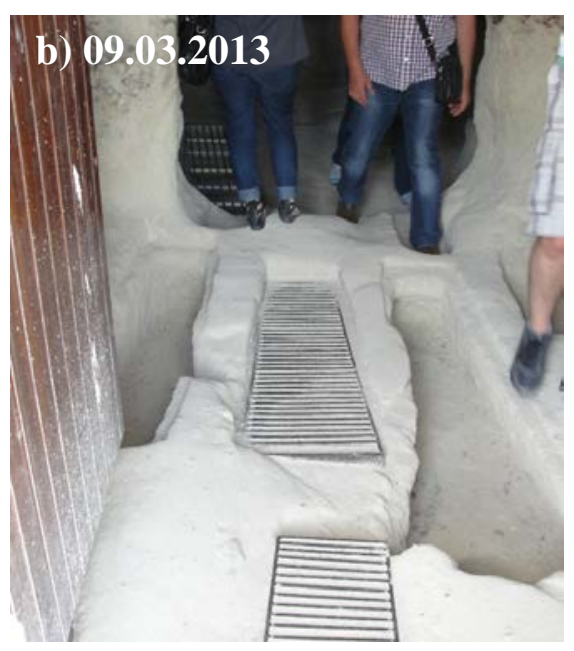

Arşivi).

Eğlence yerlerinden ve çevreden gelen yüksek seslerin de kayaçların duraylılıkları üzerine olumsuz etkisi olmaktadır. Örneğin Ürgüp Temenni Tepe'de birbiriyle bağlantılı veya bağlantısız çok sayıda kaya oyma mekân bulunmaktadır. Bu mekânlarda meydana gelen göçmeler kaya bloklarında duraysızlıklara neden olmaktadır (Şekil 2b). Kasapoğlu ve Binal (2007) tarafından tepenin çevresinde bulunan eğlence merkezi ve tören alanından gelen yüksek seslerin duraysızlıklıları tetiklediği ileri sürülmüştür [14]. Göreme Açık Hava Müzesi, Zelve Açık Hava Müzesi gibi kontrolü nispeten daha iyi olan alanların dışında Rahipler Vadisi olarak bilinen Paşabağları mevkii gibi turistlerin kontrolsüz bir şekilde gezdiği alanlar da mevcuttur. Çalışma alanında hediyelik eşya satış yerlerinin ve kaçak yapılaşmaların olduğu da görülmektedir (Şekil 12a, Şekil 12b). 1. derece doğal ve arkeolojik sit olan alanların koruma ve kullanımına ilişkin 658 ve 728 no'lu ilke kararlarına göre kesinlikle her türlü inşa eyleminin yasak olup, sadece teknik alt yapı hizmetlerine zorunluluk hallerinde ve koruma kurullarının denetiminde olmak koşuluyla izin verilebilir. Bu alanlarda bile iskân, barınma, ticaret, ahır vb. işlevlerle kaçak yapılaşmaların gerçekleştiğine ve suç duyusunda bulunulduğuna dair Nevşehir Koruma Bölge Kurulu arşivlerinde çok sayıda belge bulmak mümkündür. 

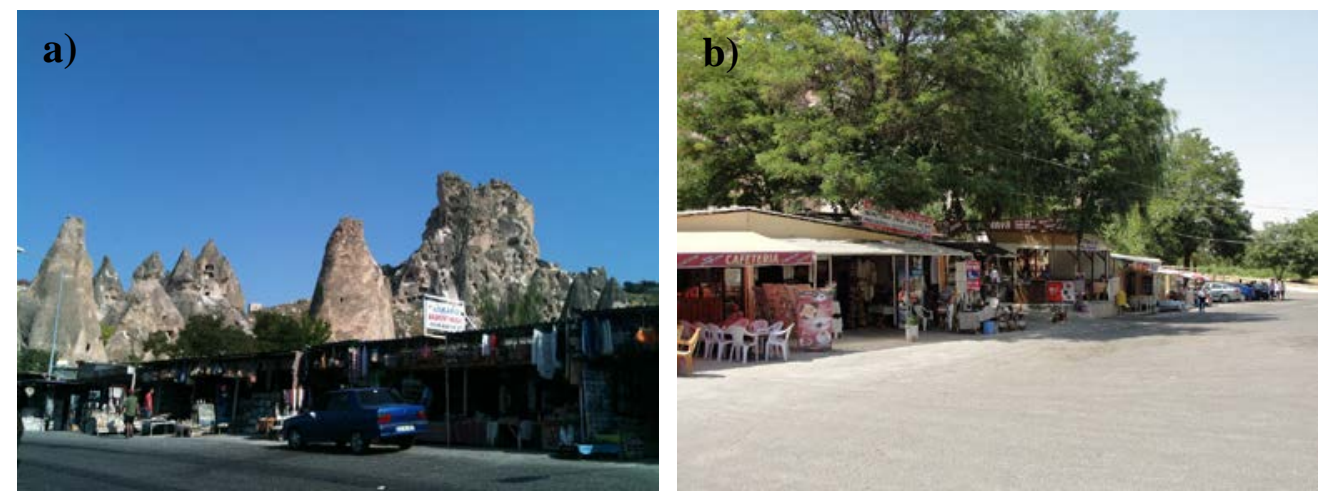

Şekil 12. a) Uçhisar mevkii, yol kenarındaki hediyelik eşya satış birimleri (B.Bilgili Kişisel Arşivi). b) Zelve ören yeri girişindeki hediyelik eşya satış birimleri (B.Bilgili Kişisel Arşivi).

Bölgedeki peyzaj bütününde geleneksel sokak dokusunun veya kaya mekânların bulunduğu kritik noktaların kamyon ve benzeri ağır taşıt trafiğine açılması, bu yollar ve çevresindeki yapılarda titreşimlere ve yapılan baskı sonucu ortaya çıkan hasarlara neden olmaktadır. Bölgede yapılan çalışmalarda Ortahisar, Ürgüp gibi geleneksel kent dokusunun yaşadığı ve dar sokakların bulunduğu merkezlerde araçların sürtmesi sonucu tarihi yapıların duvarlarında bozulmalar gözlenmiştir. Göreme Açık Hava Müzesi'nin hemen önündeki müze yolundan geçen büyük ya da hızlı araçların meydana getirdiği titreşime bağlı olarak Tokalı Kilise'nin üst kısımlarından kaya parçalarının kopup düştüğü geçmişte rapor edilmiştir. Aynı yolun Nevşehir Kültür ve Tabiat Varlıklarını Koruma Bölge Kurulu'nun 17.03.2011 tarih 2890 sayılı karar ile araç trafiğine kapatılmasına ve kaldırılmasına karar verilmiş olmasına rağmen bugün hala kullanımı söz konusudur. Ortahisar'da yoğunlaşan trafiği rahatlatmak için belediye tarafindan yol genişletme ve asfaltlama planları yapılmış, ODTÜ Mimarlık Fakültesi Restorasyon Programı tarafından 1975 yılında “Ortahisar Araştırma, Değerlendirme ve Genel Koruma Projesi” kapsamında yapılan çalışma ile yol genişletmenin tahrip edici olacağı, o zaman için zorunlu olmadığı ve gelecekte alternatif güzergâhların geliştirilebileceği ifade edilmiştir. Yakın tarihli benzer bir örnek de Ortahisar beldesi Göreme-Kızılçukur kavşağında yol genişletme talebinde görülmektedir. 1998 yılında Bölge Koruma Kurulu'nun 8m'den 12m’ye çıkarılmasını uygun bulduğu yolun 30 metreye çıkarılması talep edilmiştir. Kapadokya'nın çevre düzeni planının olmaması ve bölünmüş yola gerek olmadığı düşüncesiyle bu talep Bölge Koruma Kurulu tarafindan reddedilmiştir. Talebin tekrarı üzerine 01.02.2007/1013 tarih/sayılı karar ile 16m olmasına onay verilen Ortahisar-Kızılçukur kavşağından-proje başı olan bölümünün kesiti, izinsiz olarak 23m’ye çıkarılmıştır. Bu ve benzeri uygulamalar bölgenin doğal peyzajına zarar vermektedir [7]. Derinkuyu yer altı şehrinde de Şekil 13a'da görüldüğü gibi iklimsel koşullar, yapılaşma ve trafikten kaynaklanan dinamik yüklemelerden dolayı duraysızlık problemleri ile karşı karşıya kalındığı görülmektedir [15].

Hemen hemen bütün tarihi alanlarda örneklerine rastlandığı gibi Kapadokya Bölgesi’nde de yeni yolların açılması ve baraj yapımı tarihi çevreyi tehdit eden imar hareketlerindendir. Bölgede tüm Türkiye'de olduğu gibi hidroelektrik santrallerinin yapımı gerçekleşmektedir. ÇED raporlarında proje etki alanı içerisinde herhangi bir hassas alanın bulunmadığı, çalışmalar esnasında proje alanında herhangi bir kültür varlığına rastlanılması halinde ilgili mevzuat gereği çalışmalar durdurularak en yakın müze müdürlüğüne veya mülki idare amirliğine bilgi verileceği belirtilmekte ve ilgili kurumlardan izinler alınmaktadır. Oysa HES’lerin bölgenin iklimine ve doğal oluşumuna nasıl bir etkisinin olacağı, doğal peyzajı ve kültür varlıklarını uzun vadede nasıl etkileyeceği muammadır. Bölgenin turizm açısından önemli olmasından dolayı turizmi teşvik amacıyla otellere 5 kata kadar izin verilmektedir. Ancak bu durum bölgenin doğal ve tarihi dokusu açısından estetik bir problem yaratmaktadır. Uçhisar'da kale çevresinde yapılan turistik tesislerin kütlesel büyüklüğü ve kullanım sürecinde yapılan müdahalelerde açık ve yarı açık mekânların büyük cam yüzeylerle kapatılması da kent siluetine olumsuz etkide bulunmaktadır. Şekil 13b'de görüldüğ̈̈ gibi Gülşehir'de kente hâkim bir noktada altta bulunan kaya oyma mekânların üzerine dokuyla uyumsuz malzeme, kütle, mimari vb. açılardan farklı bir yapının inşa edilmesinin yarattı̆̆ı olumsuz durum ortadadır. 

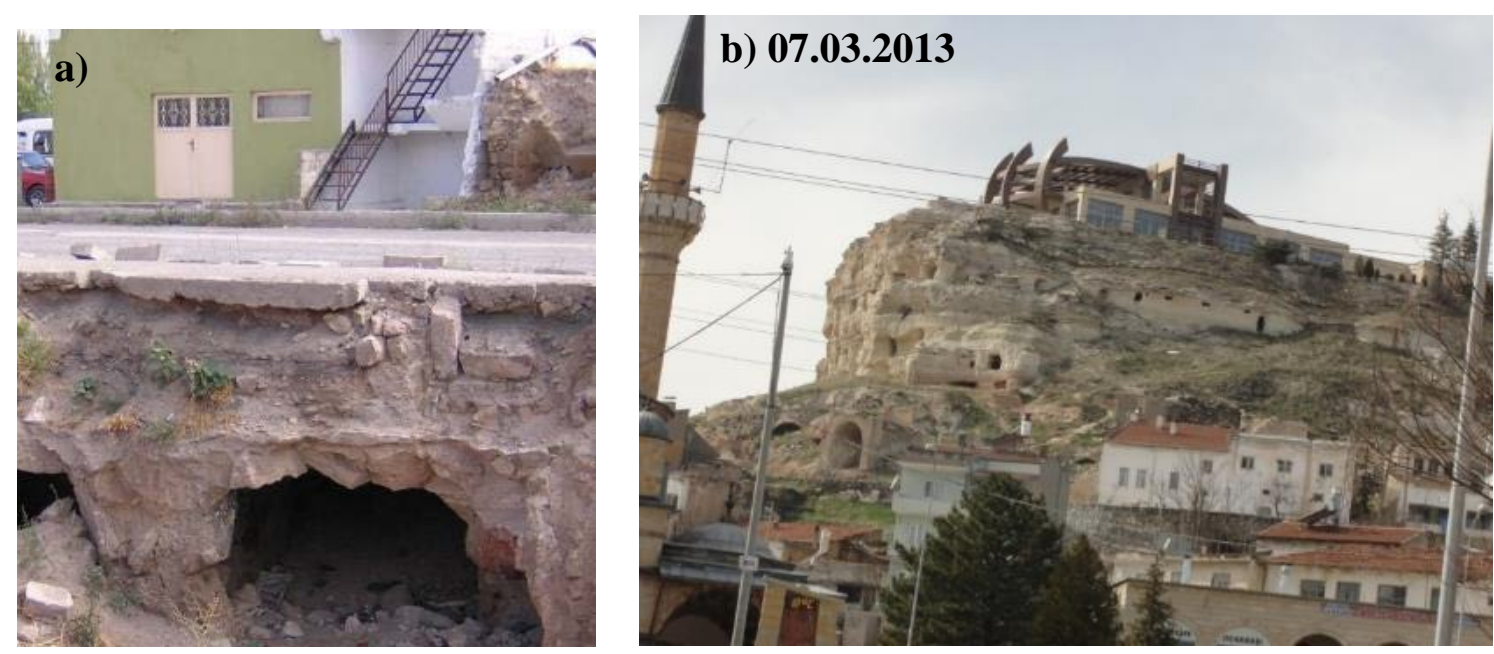

Şekil 13. a) Derinkuyu Yer altı Şehri (Aydan ve diğ. 2007). b) Gülşehir Merkez (B.Bilgili Kişisel Arşivi).

Kötü kullanım ve kötü onarımlar yapıların harap olmasına neden olan bir etkenlerdir. Terk nedeniyle boşalan yapılar depo, ahır gibi çeşitli işlevlerle kullanılmıştır. Örneğin Şekil 14a'da görülen Bezirhane Kilisesi’nin sonraları bezir yağı imalathanesi olarak kullanıldığı ve adını buradan aldığı bilinmektedir. İmalathane olarak kullanıldığ1 dönemde iç mekânlarda yüzeyler isle kaplanmıştır. Ayrıca Şekil 14a'da görülen Bezirhane Kilisesi’nde olduğu gibi kaya mekânlar araç park etmek için de kullanılmaktadır. Şekil 14b'de de Paşabağı mevkiinde jandarma asayiş noktası olarak gereksiz ve uygunsuz bir işlevde kullanılan peri bacası benzer örneklerden biridir. Bazen de kullanıcılar isteklerine göre gelişigüzel ekler yapmakta, kat eklemekte, binaların altına otopark açmakta ve strüktür düzeninde değişiklik yapabilmektedir. Bu da yapıların mekânsal bütünlüğüne ve özgünlüğüne zarar vermektedir. Ayrıca bazen bunlar yerel yöneticiler tarafından göz ardı edilmekte, bazı durumlarda da yaptırım uygulanabilmektedir.
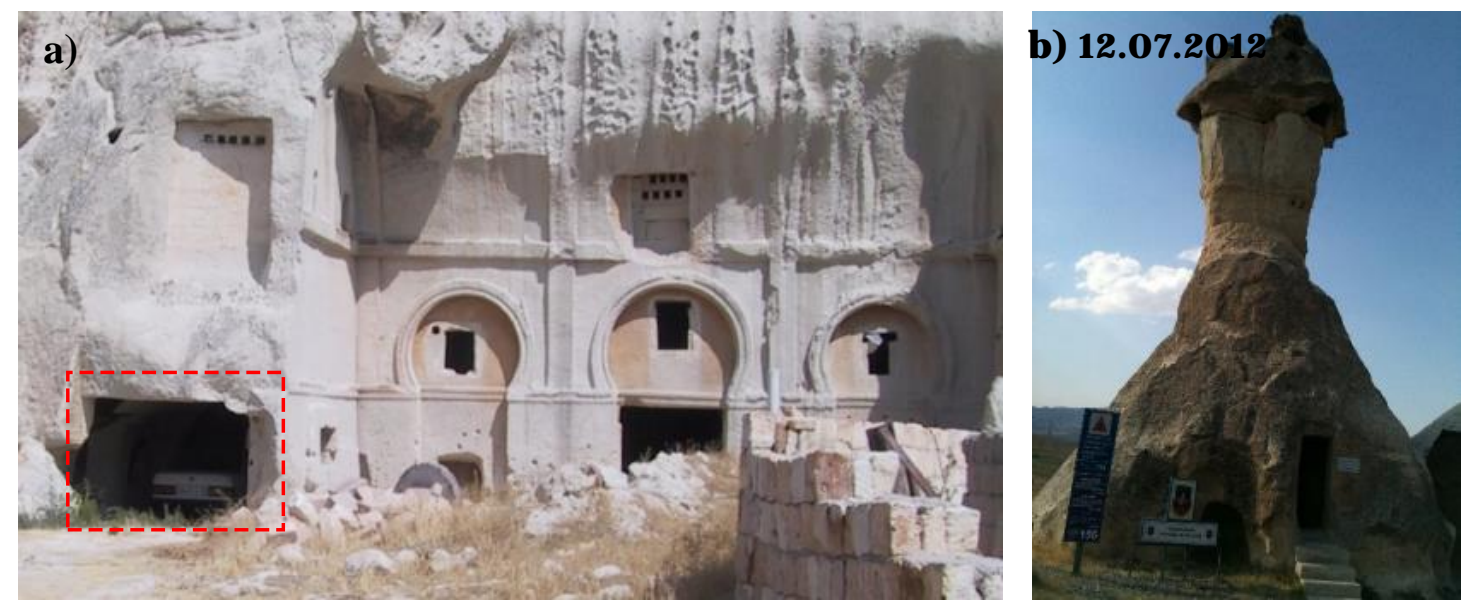

Şekil 14. a) Bezirhane Kilisesi (Faruk Sağcan Kişisel Arşivi). b) Paşabağı mevkii jandarma asayiş noktası (B.Bilgili Kişisel Arşivi).

Alan araştırmasında mimari değerleri, özgünlük ve bütünlüğü zedeleyici en yaygın müdahalelerin alttaki kaya oyma mekân ve eyvanlar üzerine yeni malzeme ve tekniklerle kat çıkılması, düz damların akmasının önüne geçmek için beton şap kaplanması, pencere büyütme, dam üzerine ya da doğal çevreye güneş panellerinin konulması gibi çeşitli biçimsel müdahaleler olduğu gözlemlenmiştir. Ayrıca uygun olmayan malzemelerle derz ve sıva yapımı gibi müdahalelere de sıkça rastlanmaktadır. Onarımı yapılan yapılarda da çeşitli detay uygulama hataları da görülmüştür. Örneğin Ürgüp Esbelli Camii yeni restore edilmiş; ancak yapının üzerine serilen membran harpuştanın altına 
yerleştirilmeyip açıkta bırakıldığından sızan sular nedeniyle de iç mekânda nemlenmeler meydana gelmiştir. Gözlenen bir diğer problem kullanılan çeşitli metal malzemelerin (çivi, tel, kenet) zamanla korozyona uğrayarak taşları patlatması ya da üzerindeki sıvayı atması ve renk değişimlerine neden olmasıdır. Onarımlarda görülen kötü işçilik ve detay kullanımları hem uygulamaların koruma açısından başarısız olmasına neden olmakta hem de sunum açısından estetik problemler yaratmaktadır. Derzlemelerde, renk ve dayanım açısından seçilen malzemelerde, taş malzemenin uygulanış biçiminde teknik ve estetik problemler, kaya oyma yapıların ve yığma sistem yapıların onarımlarında kendini göstermektedir. Mukavemeti düşük taş malzemelerin dış mekânda, uygun olmayan kullanımında birkaç sene içerisinde tamamen tahrip olması buna örnek olarak verilebilir. Bunların yanında turizm yönünden gözde merkezlerde, kentsel sit içerisinde yapılacak binaların tarihsel görünüme sahip olması isteği, farklı bölgelerdeki sivil mimarlık örneklerinin yapı taşlarının çalınarak satılmasına ve geleneksel dokunun tahribatına neden olmaktadır.

\section{Tartışma ve Sonuç}

Dünya Miras Alanı olarak Kapadokya Bölgesi çok sayıda bilimsel çalışmaya konu olmuş ve olmaya devam eden bir alandır. Çalışmaların ağırlıklı olarak konusunu jeoloji ve sanat tarihi araştırmaları oluşturmaktadır. Bölgenin korunmasına yönelik çalışmalar ise daha sınırlıdır. Bu çalışma kapsamında, doğal ve kültürel değerlerin bozulmasına neden olan etmenler çeşitli araştırmalara ve kişisel gözlemlere dayanarak mimari koruma eylem alanı içerisinde ele alınmış ve değerlendirilmiştir. Buna göre, koruma uygulamalarında müdahale kararlarının ve gerekçelerinin koruma kuram ve ilkeleriyle uyumlu olması, bozulma ve bozunma süreçlerinin anlaşılmasıyla oldukça ilişkilidir. Bu bakımdan restorasyon uygulamalarında Kapadokya Bölgesi'nde yıllar süren araştırmalardan, deneysel çalışmalardan faydalanılmalı ve bozulma etkinliklerini önleyici tedbirler alınmalıdır. Doğa ve insan kaynaklı bozulmaların önlenmesinde kültür varlıklarının periyodik kontrollerinin yapılması, gerekliyse müdahalenin hızlı bir şekilde gerçekleştirilmesi hayati önem arz etmektedir. Söz konusu problemlerin bütününe bakıldığında yönetim ve planlamadan kaynaklı sorunların öncelikli olduğu anlaşılmaktadır. Kapadokya Bölgesi'nde çok parçalı bir yönetim ve planlama anlayışı mevcuttur. Koruma Amaçlı İmar Planlarının tamamlanmaması, turizm yönetim planının olmaması, parçacı yaklaşımlarla alan planlamasının yapılması sonucu alt ve üst ölçekli planların çakışmaması ya da restorasyon uygulamalarında dil birliğinin olmaması gibi sorunlar bir an önce çözülmeli, doğal ve kültürel çevreye zarar vermeyecek şekilde planlama ve uygulamalar yapılmalıdır. Böylece trafik, imar etkileri, vandalizm, turizm, kötü kullanım ve kötü onarımlar gibi insana bağlı tahribatların önüne geçmek mümkün olabilir. Bu bakımdan Kapadokya Bölgesi’nin korunmasının farklı disiplinlerden uzmanların yer aldığı çok yönlü, kapsamlı planlama ve projelendirme çalışmaları ile sağlanabileceği açıktır.

\section{Teşekkür}

Bu çalışma İTÜ Mimarlık Fakültesi Mimarlık Bölümü Restorasyon Programı'nda “Kapadokya Kayalık Alanları ve Kaya Oyma Kiliseleri’nde Koruma Sorunları” başlıklı yüksek lisans tezinden türetilmiştir. Çalışmanın hazırlanması sürecinde desteklerini esirgemeyen danışmanım Yrd. Doç. Dr. Gülsün Tanyeli’ye, Nevşehir Koruma Bölge Kurulu Eski Müdürü Mevlüt Coşkun’a, Ürgüp Fen İşleri Eski Müdürü Ali İren’e ve Mimar Ahmet İren’e teşekkür ederim.

\section{Kaynaklar}

[1] Binan, D.U., “Güzelyurt Örneğinde Kapadokya Bölgesi Yığma Taş Konut Mimarisinin Korunması İçin Bir Yöntem Araştırması” Yıldız Teknik Üniversitesi, Fen Bilimleri Enstitüsü, Doktora tezi, İstanbul, 1994. 
[2] Binan, D.U., “Kapadokya Bölgesi Güzelyurt Örneğinde Yöresel Konut Mimarisi Koruma Sorunları ve Öneriler” Ulusal Koruma Planlaması Semineri II, ICOMOS Türkiye Milli Komitesi -YTÜ, YTÜ Yay., s.254274, İstanbul, 1994.

[3] Giovannini, L., “Arte Della Cappadocia” Nagel Yay. s.76-77, Geneve, 1971.

[4] Wyllie, D.C and Mah, C.W., "Rock Slope Engineering Civil and Mining” London-New York: Taylor \&Francis Group, Spon Press, 2005.

[5] Canik, B., “Göreme Yapısal Sağlamlaştırma Projesi”, Üçlü Değerlendirme Toplantısı, Nevşehir Bölge Koruma Kurulu Arşivi, 1986.

[6] Ulusay, R., Aydan, Ö., "Kapadokya Bölgesinde Bazı Yeraltı Açıklıklarındaki Tüflerin Kaya Mühendisliği Açısından Değerlendirilmesi”, Kapadokya Yöresinin Jeolojisi Sempozyumu, Bildiriler Kitabı, s. 13-23, Niğde, 2007.

[7] Bilgili, B., “Kapadokya Kayalık Alanları ve Kaya Oyma Kiliseleri’nde Koruma Sorunları” İstanbul Teknik Üniversitesi, Fen Bilimleri Enstitüsü Yayımlanmamış Yüksek Lisans Tezi,333s, İstanbul, 2014.

[8] Aydan, Ö., Tano, H., Watanabe, H., Ulusay, R., Tuncay, E. “Kapadokya Bölgesi’nde Antik ve Güncel Kaya Yapılarının Kaya Mekaniği Açısından Değerlendirilmesi” Kapadokya Yöresinin Jeolojisi Sempozyumu, Bildiriler Kitab1, s. 1-12, Niğde, 2007.

[9] Topal, T. ve Doyuran, V., “Analyses of Deterioration of the Cappadocian Tuff”, Environmental Geology, 34, 5-20, 1998.

[10] Topal, T., "Formation and Deterioration of Fairy Chimneys of the Kavak Tuff In Urgup-Goreme Area (Nevşehir-Turkey).” METU, Yayımlanmamış Doktora Tezi, 250 p., Ankara,1995.

[11] Caner, E., “Göreme Yapısal Sağlamlaştırma Projesi”, Üçlü Değerlendirme Toplantısı, Nevşehir Bölge Koruma Kurulu Arşivi, 1986.

[12] Caner-Saltık E.N., Demirci Ş., Türkmenoğlu A., Özgenoğlu A., Göktürk H., Özer A., Böke H.,, İnalpulat E. "Examination of Surface Deterioration of Goreme Tuffs for the Purpose of Conservation," The Safeguard of the Rock-Hewn Churches of the Goreme Valley, Proceedings of an International Seminar, pp.85-93, Ürgüp, Cappadocia, Turkey, 5-10 September 1993, ICCROM Publication 1995.

[13] Andoloro, M.. “Küçük Asya Duvar Resimleri ve Mozaikleri: Tasvirler, Malzemeler ve Yapım Teknikleri üzerine Veri Bankası Oluşturulması amacıyla gerçekleştirilen araştırma projesi”, Şahinefendi Kırk şehitler Kilisesi 2009 yılı çalışma raporu, Nevşehir Koruma Bölge Kurulu Arşivi, 2009.

[14] Kasapoğlu, K. E., Binal, A., “Ürgüp Temenni Tepe’deki Blok Duraysızlıklarının Jeomekanik İncelemesi ve İyileştirme Önerileri.” Kapadokya Yöresinin Jeolojisi Sempozyumu, Bildiriler Kitabı, s. 43-52, Nevşehir, 2007.

[15] Aydan, Ö., Tano, H., Ulusay, R., Kumsar, H.,Yenipınar, H., "Derinkuyu Yeraltı Şehrinin Uzun Süreli Yapısal Duraylılığı ve Çevre Koşullarının İncelenmesi Üzerine Deneysel Bir Çalışma”, Kapadokya Yöresinin Jeolojisi Sempozyumu, Bildiriler Kitab1, s. 24-34, Niğde, 2007.

[16] Bilgili B., Tanyeli G., "Kapadokya Kaya Oyma Kiliselerinde Gerçekleştirilen Restorasyon Çalışmalarının Değerlendirilmesi." 4. Tarihi Eserlerin Güçlendirilmesi ve Geleceğe Güvenle Devredilmesi Sempozyumu, Bildiriler Kitab1, s. 23-32, İstanbul, 2013. 